\title{
Going rogue for raw milk: Experience and values as consumer filters for conflicting raw milk discourses
}

\author{
Sarah N. Heiss ${ }^{a *}$ and Andrea Suozzo ${ }^{b}$ \\ University of Vermont
}

Submitted September 13, 2019 / Revised November 18 and November 21, 2019 / Accepted November 25, 2019 /

Published online May 21, 2020

Citation: Heiss, S. N., \& Suozzo, A. (2020). Going rogue for raw milk: Experience and values as consumer filters

for conflicting raw milk discourses. Journal of Agriculture, Food Systems, and Community Development, 9(3), 301-315.

https://doi.org/10.5304/jafscd.2020.093.034

Copyright (C) 2020 by the Authors. Published by the Lyson Center for Civic Agriculture and Food Systems. Open access under CC-BY license.

\begin{abstract}
Consumption of raw milk has long been a hotly debated topic: government entities, medical professionals, and advocacy groups often present different reasons in support of or opposition to raw milk, creating a particularly difficult environment for consumers to navigate. Through semistructured interviews, this paper examines consumers in Vermont who have decided to consume raw milk, exploring their experiences with raw milk and their reasons in support of it. It was found that consumers of raw milk often prioritize personal experiences and local networks over scientific expertise when it comes to raw milk consumption. The process of conducting their own research about raw milk has also helped create a community of more conscious consumers. This case study ends with a set of suggestions that may be helpful for other communities. Specifically, we discuss
\end{abstract}

a * Corresponding author: Sarah N. Heiss, Ph.D., University of Vermont; 208F Morrill Hall; Burlington, VT 05405 USA; sarah.heiss@uvm.edu

b Andrea Suozzo, M.S., University of Vermont; 109 Carrigan Drive; March Life Science, Room 236; Burlington, VT 05405 USA. marketing strategies to promote raw milk, as well as risk communication strategies for regulators and public health officials seeking to minimize its consumption.

\section{Keywords}

Consumer Decision-Making, Dairy, Food Systems, Risk, Raw Milk, Unpasteurized

\section{Introduction}

Studies have shown that raw milk is much better than pasteurized milk for building strong bones and teeth, and for creating resistance to disease. Raw milk protects against allergies and asthma and often improves behavior in children.

(Weston A. Price Foundation, 2011, p. 22) 
Drinking raw milk is "like playing Russian roulette with your health." - John Sheehan, Food and Drug Administration Division of Dairy and Egg Safety (quoted in Hannon, 2009, para. 4)

Raw milk "provides a viable market niche for dairies."

(National Farmers Union, 2013, p. 17)

Any foodborne illness outbreak related to dairy products damages consumer perception of milk in general, even when the source of the problem is clearly attributed to raw milk or raw milk products.

(American Farm Bureau, 2013, para. 6)

The debate over raw milk is polarizing, with parties speaking passionately both in support of and in opposition to its availability and consumption. Those on each side of the discussion make broad-and sometimes dire-knowledge claims regarding benefits and risks associated with raw milk consumption. As illustrated by the epigraphs above, advocacy groups, agricultural associations, and various governmental authorities all voice divergent opinions regarding raw milk safety and health benefits. Therefore, consumers navigate these contests of voices when deciding whether or not to drink raw milk.

In an instance of such contestation, the Vermont General Assembly voted in 2009 to allow dairy farmers to sell their unpasteurized product, against the recommendation of the federal government, which forbids interstate transport of raw milk and strongly recommends that states outlaw it (Sawyer, Calderwood, Bothfeld, \& Perkins, 2010; Weisbecker, 2007). Vermont is now one of 38 states that allow raw milk sales in some capacity (Rhodes, Kuckler, McClelland, \& Hamrick, 2019); advocates within the state cite consumer demand and high prices of raw milk as reasons for allowing farmers to sell it (Rural Vermont, 2019). A 2013 statewide survey found that $11.6 \%$ of Vermonters had consumed raw milk in the past year (Leamy, Heiss, \& Roche, 2014).

Voices of raw milk consumers themselves are often drowned out amid conflicting governmental and advocacy group recommendations. Yet raw milk consumers are not simply passive recipients of governmental, advocacy, and media messagingrather, they are consumers making decisions based on their research, experience, and values. More research is needed to understand how consumers who drink raw milk evaluate conflicting recommendations surrounding its consumption (Leamy et al., 2014).

In this study, we examine how raw milk consumers integrate widely varied health and risk discourses into personal consumption decisions. We argue that personal experiences, relationships, and values offer a lens through which consumers interpret and filter these contested voices and ultimately make personal consumption decisions. In examining how raw milk influences consumer decisionmaking processes, we contribute to the larger discussions regarding consumer behaviors amid health and safety debates regarding food, as well as those specific to raw milk.

\section{Raw Milk in Vermont}

As of 2011, 30 states allowed raw milk sales in some capacity. Although all 30 have stricter standards in place for raw milk sales than for pasteurized, these state policies allow access to a substance that the federal government says is categorically dangerous. Regulations vary widely by state, with some states allowing raw milk sales only from the farm, some enforcing stringent quality and testing standards, some allowing only raw goat milk sales, and two states-Kentucky and Rhode Island-allowing sales of raw milk only with a doctor's prescription (National Association of State

Departments of Agriculture, 2011).

Federal government policies are based on discourses that assert that raw milk is dangerous and forbid raw milk sales across state borders, while Vermont laws that permit on-farm raw milk sales are more permissive. When the General Assembly voted to permit limited sales of unpasteurized milk in Vermont (Sale of Unpasteurized Milk Act, 2009), the state became part of a small-scale reversal of the early $20^{\text {th }}$-century push for sanitization and standardization of the milk supply (NASDA, 2011). Pasteurization - heat treatment to kill bacteria-came into widespread practice in the U.S. be- 
tween 1900 and 1940 along with a variety of other sanitary measures, most aimed at addressing urban disease epidemics that had been traced back to the rural milk supply (DuPuis, 2002). These measures, in turn, enabled greater production and distribution of dairy products. With state and local governments leading the charge to demand clean milk, pasteurization became nearly universal over 30 years, bringing an accompanying decline of foodborne illnesses such as typhoid and cholera (DuPuis, 2002). Producers and distributors favored the practice once they noted that pasteurized milk had a longer shelf life and thus could be distributed further (U.S. Food and Drug Administration, 2011).

Resistance to pasteurization in the early 1900s made up a small but vocal minority. Some of those voices are reflected in contemporary raw milk advocacy efforts, as well as in state policies regarding the sale of raw milk. The recent pushback against pasteurization has been spurred, in part, by groups arguing that raw milk benefits farmers, as they can sell it directly to consumers and at a higher cost, and that raw milk offers health benefits which pasteurized milk does not. For example, the Weston A. Price Foundation is a national organization that distributes information to consumers about the health benefits of raw milk and participates in national policy discussions about its legalization (Weston A. Price Foundation, 2000). Rural Vermont (2019) is a farmer advocacy group that has played a large role in policy discussions around loosening the state laws restricting raw milk sales.

In Vermont, producers may only sell fluid raw milk: they may not process it into yogurt, cheese, butter, or any other substance. Producers face strict limits on the total quantity of milk they are allowed to sell, and larger producers face strict bacterial testing requirements. Producers who sell raw milk must post a sign that states "This product has not been pasteurized and therefore may contain harmful bacteria that can cause illness particularly in children, the elderly and persons with weakened immune systems, and in pregnant women can cause illness, miscarriage or fetal death, or death of a newborn" (Sawyer et al., 2010, pp. 59-60). In this way, the state frames raw milk as a "risky" substance and reduces its own responsibility for any illnesses caused by consumption.

Despite governmental cautions against raw milk consumption and limited, if any, research supporting the safe consumption of raw milk, a limited body of research suggests that some people are still choosing to consume raw milk. An American Time Use Survey_Eating and Health Module found that from 2014 to 2016 an estimated 3.2 million people each week consumed or served raw milk (Rhodes et al., 2019). In Vermont, the 2013 annual Vermonter poll found that $10.7 \%$ of respondents said that they had consumed raw milk within the past year (Leamy et al., 2014). Though these consumers were generally aware of government discourses regarding the health risks of raw milk, they primarily cited flavor, health benefits, and acquaintance with their farmer as reasons that they choose to drink raw milk. A 2011 survey of 56 raw milk drinkers in Michigan found that only four respondents said that they "generally trusted recommendations made by state health officials regarding what foods are safe to eat" (Katafiasz \& Bartlett, 2012, p. 125), demonstrating a general mistrust of governmental recommendations among raw milk drinkers.

\section{Discourse and Food Risk}

In a society that considers many forms of risk, consumers are faced with a plethora of discourses regarding the healthfulness and riskiness of foods. In this landscape, advice on eating choices, risks, and benefits may come from scientists and dietary professionals. However, it may also come from members of the media and the general public, as well as any number of advocacy or trade groups. Rahn, Gollust, and Tang (2017) describe how strongly debated policies such as raw milk regulation cause the public to receive mixed messages from various influences, such as advocacy organizations, interest groups, professional associations, and public officials, who try to sway the public toward their policy position. Further, Fuentes and Fuentes (2015) note that these differing opinions can create anxieties over food choices among consumers, due to their heightened awareness of possible risks and various means of responding to risks.

Shifting discourses on nutrition and health have thrust pasteurization - once hailed as the ulti- 
mate way to mitigate dairy risk-into a newly contested space. In the early $20^{\text {th }}$ century, municipal and state governments turned to pasteurization as a way to ensure a clean and disease-free milk supply for their population. While the switch to pasteurization was not nearly so monolithic a switch as it seems today, the prevailing discourse of dairy safety throughout the $20^{\text {th }}$ century, however, has held that pasteurization is necessary for the safety of the milk supply (DuPuis, 2002). Certain advocates and scholars have problematized this discourse, driving the rise of what Paxson (2013) has termed "post-Pasteurian" beliefs, which question the push to rid bacteria from the food system. The post-Pasteurian view "emphasizes the potential for cooperation among agencies of nature and culture, microbes and humans" (p. 161). This idea has become widespread in the popular food press, including a New York Times Magazine cover story, "Some of My Best Friends Are Germs," in which Michael Pollan (2013) discusses the so-called "good bacteria" that help the human body to function, noting that these bacteria may be supplemented and stimulated by vegetables and certain fermented and raw foods-like milk.

Many food and animal scientists, on the other hand, adopt what Paxson calls "Pasteurian" attitudes, citing the dangers and strongly opposing the practice of drinking raw milk. Donnelly and Pritchard (2010) stated that "despite claims of health benefits associated with raw milk consumption, raw milk is a well-documented source of bacterial pathogens which can cause human illness, and, in some instances, death" (p. 2). For example, reports cite " 12 confirmed infections and five probable cases of Campylobacter jejuni infections identified in persons who consumed raw milk from a herdshare dairy in Colorado" between August and October 2016 (Burakoff et al., 2018, p. 148). In addition, a recent study that tested raw drinking milk in England found 59\% of the samples to have safe bacteria within all parameters, and 1\% contained bacteria considered potentially dangerous to health (Willis et al., 2017). Over the last two decades, bacterial pathogens have become stronger; particularly, since reducing the cost of health care is a high priority in both Vermont and the U.S., "increased raw milk exposure will only contribute to the economic burden of increased health care costs due to [E. coli 0157:H7, which is associated with acute kidney failure in infants and which easily contaminates fresh milk] and other pathogens (Donnelly \& Pritchard, 2010, p. 5).

In the U.S., the most severe cautions come from the FDA and the CDC. Although these authorities generally do not prioritize messages about the risk of foodborne illness over fostering a healthy microbiome of bacteria, the FDA raw milk informational page clearly states its concern regarding the public health costs of raw milk. It leads with "Is it safe to consume raw milk?" to which it bluntly responds, "No" (FDA, 2011). The FDA cites the CDC and the American Academy of Pediatrics as organizations that agree with its stance that unpasteurized milk is unsafe, citing E. coli, listeria, brucella, and salmonella as just some of the pathogens that occur in raw milk. As FDA official John Sheehan put it succinctly in an epigraph at the beginning of this paper, "It's like playing Russian roulette with your health" (Hannon, 2009).

Enveloped in the contest of voices regarding health and risks, consumers can become frustrated with the lack of definitive answers about what to or not to eat. Östberg (2003) concluded that consumers experience "everyday anxiety due to the salience of food and health-related questions and the difficulties involved in finding pertinent answers to those questions" (p. 220). Paxson (2013) argued that "the contraindication of experiential knowledge may lead laypeople to dismiss the authoritative knowledge of scientific experts as overreaching or even beholden to industry interests" ( $p$. 165). That is, consumer experiences may outweigh cautionary and scientific and governmental discourses. Enticott (2003) found that instead of accepting the health-based portrayal of raw milk risk, consumers whom he interviewed in a small town in England framed health as only one of a variety of important factors in their decision to drink raw milk. In the face of warnings about bacteria in milk, he noted, "consumers may over-ride them with concerns for their community and locality" ( $p$. 413-414). Enticott's interviewees were aware of presiding risk discourses, but chose other measures as the final arbiter of their behavior. Valchuis, Conner, Berlin, and Wang (2015) also cite that many 
consumers prioritizing local food sources as an important factor in food purchasing. Although purchasing locally is important, consumers must be careful to weigh their options carefully to avoid the "local trap," the tendency for consumers to associate "local" with desirable outcomes (Born \& Purcell, 2006).

In the U.S., a limited body of research suggests that people are choosing to consume raw milk despite governmental warnings. In one of the few recent state surveys, a 1994 California study found that of 3,999 respondents, approximately $3.2 \%$ had consumed raw milk in the past year (Headrick, Timbo, Klontz, \& Werner, 1997). A 2011 Michigan study that surveyed only raw milk drinkers found a great deal of mistrust of government recommendations among the 56 people interviewed: only four respondents said they "generally trusted recommendations made by state health officials regarding what foods are safe to eat" (Katafiasz \& Bartlett, 2012, p. 125). Both Michigan and California have raw milk regulatory structures and overall population demographics that are very different from Vermont, however.

More recently, Leamy et al. (2014) found that in $2013,11.6 \%$ of Vermont consumers had obtained raw milk within the past year. The survey, representative of the state population, found that the majority of raw milk drinkers lived in rural areas, and that the average raw milk drinker was middle-aged and had a bachelor's degree or higher. It was also found that raw milk drinkers get information about raw milk primarily through farmers and personal networks. Since the study consisted of a brief phone survey, the authors called for further research into how consumers evaluate information they receive about raw milk and how they "make sense of divergent recommendations regarding raw milk" (p. 224).

Our research seeks to fill that gap, drawing on the voices of raw milk consumers to examine how consumers evaluate information they receive about raw milk and how they make sense of those external recommendations and their own experiences. Specifically, we asked, How do consumers make decisions regarding their personal raw milk consumption amid conflicting discourses surrounding raw milk consumption, health, and risk?

\section{Methods}

\section{Interview Data Collection}

The snowball technique (Polkinghorne, 2005) was used to identify a "pool of possible participants" (p. 141). We reached 25 people who regularly purchase and drink raw milk and who were willing to participate in an approximately 45-minute-long, one-on-one interview. We selected raw milk drinkers only within Vermont in order to maintain consistency in our discussions of state-specific raw milk policies. We recorded the audio of each interview.

A semistructured interview format was used. The team worked together to develop a set of interview questions about consumption behaviors and knowledge of public discourses surrounding raw milk. The semistructured format allowed the research team to have consistency across interviews while also allowing for some "freedom to digress" (Berg, 2004). The research team talked weekly about their interviews to ensure that researchers were asking about similar topics and digressing from the interview protocol in similar ways.

\section{Characteristics of the Interview Study Population}

Out of the 25 interviewees, 20 were female and 5 were male. Two did not respond to our initial data collection survey. Of the survey respondents, nine had a bachelor's or associate's degree, and 14 had a master's or doctorate. Eight had a household income of $\$ 50,000$ or less per year, while 15 had a household income of more than $\$ 50,000$ per year; one did not answer. All interviewees were regular raw milk drinkers, consuming at least one glass of raw milk per month. Thirteen said they drank more than eight glasses of raw milk per month. Nineteen reported also consuming pasteurized milk within the last year.

\section{Interview Data Analysis}

For the analysis, we entered the interview text into HyperRESEARCH (ResearchWare, 2012) qualitative research software in order to code the data for emergent themes and patterns. At this point, we assigned pseudonyms to each interviewee.

We developed our aims and research focus using a "constant comparative" process (Glaser \& 
Straus, 1967), in which various parts of the research process happen simultaneously, guided by constant examination and comparison of the data to reveal recurring themes. In its most common form, "categories, properties, and dimensions as well as different parts of the data are constantly compared with all other parts of the data to explore variations, similarities and differences in data" (Hallberg, 2006, p. 143).

Our process followed that of inductive thematic analysis, in which the research has "a descriptive and exploratory orientation" (Guest, MacQueen, \& Namey, 2012, p. 7) as opposed to a process "guided by specific ideas or hypotheses the researcher wants to assess" (p. 8). The recurring themes that emerged through background reading and interview coding formed the structure for our analysis.

\section{Analysis}

We argue that while consumers were aware of multiple raw milk discourses, they believed that the information regarding raw milk, health, and risks often conflicted. Instead of relying on the risk and health discourses surrounding raw milk consumption, interviewees relied on the filters of personal experience and personal networks to create decision-making criteria regarding raw milk.

In this section, we examine how interviewees make decisions about their personal raw milk consumption amid conflicting discourses surrounding raw milk consumption, health, and risk. First, we describe how interviewees interpreted tensions between cultural raw milk discourses. Then we discuss the ways in which interviewees applied their own experiences and observations in order to draw their own conclusions about raw milk.

\section{A Contest of Voices}

Interviewees identified a range of competing governmental, scientific, and advocacy discourses that presented raw milk as anything from a high-risk and dangerous substance to a healthy and beneficial beverage. Almost all had done extensive research as part of their decision to drink raw milk. Interviewees generally recognized various opinions and opposing recommendations surrounding raw milk, health, and risk in mediated sources. Many brought literature and sources to interviews, including internet sources, books, videos, educational events, and official publications. This information generally separated into three perspectives on raw milk consumption: federal, state, and advocacy.

\section{Federal regulation}

Interviewees tended to have strong opinions regarding prohibitive federal discourses on raw milk consumption. While interviewees had various perspectives on the need for these prohibitions on a national scale, none felt that this discourse applied directly to their own consumption habits. Walter stated that federal discourses on the health risks of raw milk are completely wrong: "I have people that I trust who I think are on the right side of the issue, and I totally ignore what the government says because they have no credibility. I do my own research." He felt that political and lobbying forces influenced governmental restrictions on raw milk and that the federal government was not a trustworthy source of information on the probability of risk.

Sibyl had similar skepticism of federal warnings, but she moderated her statements by considering scale as a factor in milk safety:

People get sick from drinking pasteurized milk, too, you know. There are issues, and I think that a lot of it comes down to scale and size and operation of farm and that kind of thing. And, so I think just blanketly saying that you shouldn't drink raw milk kind of misses the whole point.

Sibyl, like Walter, did not feel that federal representations of risk were relevant to her, but she suggested that there were certain scenarios where federal regulations would be applicable. To her, the scale of milk production changed the probability of risk, and raw milk from a smaller farm presented a very small amount of risk. While she acknowledged that there were instances when raw milk might be risky to consume, Sibyl used scale as a criterion to filter the federal risk discourse.

Kate, too, was skeptical of the federal risk discourse, but noted that she understood why these recommendations were in place. Of pasteurized 
milk from the grocery store shelf, she said, "I know that it's been in so many places and done so much traveling through so many hands and so much equipment." To Kate, this meant that the national milk supply was potentially unsafe, so pasteurization within this type of system made sense. Yet she understood these cautions to be primarily relevant within one type of agricultural system, whereas she felt that different rules applied within the Vermont system: "In my particular case, I have the luxury to ignore their recommendation because I feel like for me, where we live, I have another option." Kate concluded that her own purchases at a small Vermont farm fell outside the large-scale system to which federal risk discourses applied. She filtered those risk discourses through a systemic lens and concluded that her own raw milk consumption required different risk considerations than a purchase of milk at the grocery store.

\section{Vermont regulation}

There was a significant amount of variance in how familiar participants reported being with the Vermont state regulations of raw milk. Many interviewees said that they did not know the Vermont regulations allowing consumption of raw milk well. For example, Maggie said, "I know it changed a few years ago, so to now allow raw milk sales on farm. Actually, I don't know what it was before, if it was considered illegal ... and now-now it isn't." When asked about Vermont's raw milk regulations, Holly said "I don't know-I mean I've never really, like, read a list of rules or regulations." Even when other interviewees expressed a vague familiarity with the state's regulation of the product, they relied heavily on access to the product as an indicator of its legality. For example, Walter said, know, "I don't really even know the laws here in Vermont, I just knew that raw milk was available if you went to the farm." Similarly, Barbara said "I don't know the ins and outs of the policies. I know that [farmer name] cannot advertise her milk. She can only sell a certain amount a day. And that's about what I know for Vermont." Walter and Barbara trusted the accessibility of raw milk sales as an indicator that Vermont policy permitted raw milk consumption and sales.

While some participants based their under- standing of Vermont policy on accessibility of raw milk, some participants felt very well informed. Sibyl explained that "we've watched the evolution of the law creating more opportunities for that [raw milk consumption]." Sibyl explained that she paid attention to state regulations because providing her family with raw milk to consume was important to her. When describing their knowledge of Vermont state policy, participants commonly referred to their understanding of other state-level policies governing raw milk. Describing Vermont raw milk regulation, Hannah said, "[Vermont] got the law ... they can sell a higher quantity per day off the farm, but they still can't sell it in stores. Now in New Hampshire and California and some other places, you can actually sell raw milk in stores." Kate similarly compared Vermont policy to California, "where raw milk is — can be sold in stores." Kenny said, "in North Carolina, which has a slightly different food and agricultural culture, raw milk sellers are still legal down there." By understanding multiple state policies, these interviewees were able to understand the evolution of Vermont regulations.

In general, interviewees felt that Vermont laws regarding raw milk were more in accordance with their own beliefs about risk. Shannon said that she felt state regulations allowed her the leeway she wanted in her decisions to drink raw milk: "I don't really see [my decisions] as pushing back against Vermont's policies, because Vermont's policies are not so strict that I have to circumvent or go around them." Shannon was in compliance with Vermont laws in her raw milk consumption. Her words, however, implied that even if state policies forbade the consumption of raw milk, she would still "circumvent" those policies in order to drink it.

Interviewees voiced support for state laws for the most part; however, there were interviewees who felt that Vermont policies were restricting their behavior. Purchasing behaviors were particularly salient. Bridget explained that she and other raw milk advocates challenge Vermont's policies "cause our state does not allow the sale of raw milk in commercial locations. It has to be directly through the farmer and directly from the farmer." When explaining her desire to see Vermont regula- 
tions change, Sibyl explained, "I've spent some time in Maine and, like, you can walk into the grocery store in Maine and buy raw milk." For Bridget and Sibyl, the difficulty of consumer access was a source of frustration. Walter was also concerned by Vermont regulations that restricted sales. He explained, "the problem is that very few places are like Vermont and like this area where you can have access to it. It's-it's against the law just to ship it across state lines and most states have laws against selling it, so it's really unfortunate." Walter was frustrated that consumers outside Vermont could not easily access Vermont raw milk and upset about the restricted market for Vermont farmers. Walter said he believed "the government should not place any obstacles in the way of consumers who want raw milk."

Another frustration among Vermont raw milk consumers were laws that forbid on-farm sales of anything other than unprocessed fluid milk, including skim milk, cream, raw milk cheeses, and yogurt. Those who expressed this frustration felt the requirement was needlessly restrictive. Many said they prepared their own products with the raw milk. For example, Holly said, "I don't know how often I participate in civil disobedience. But this is an act where I'm proud to, you know, make my own raw milk products off the farm and consume them, which it's still like a gray legal area at this point." This participant perceived their consumption of raw milk and cooking with raw milk to be a questionable act within state law, yet they took pride in pushing the legality of their actions.

In addition to feeling restricted in consumption practices, some participants expressed a level of frustration regarding consumers' ability to make informed and free choices about raw milk consumption. Jon explained that, "it's great that you can sell it here at all, but I just think that that giant white sign that says this will kill your baby is a little confusing." Though Jon consumed raw milk, he expressed that the point-of-sale risk messages, even in a state that permits the sale or raw milk, were likely confusing to some audiences. Hannah also believed that is was difficult for consumers to make informed and free choices about raw milk consumption. She explained, “I don't think the average consumer is as well informed as they could be. It's definitely a jumbled up mess at this point. But I think it's really good that we have those options [to buy and sell raw milk, as well as educate consumers]."

Bridget situated consumer confusion within a tension between state and federal messages. She said that, "it's really on us [the consumer] to make our own decisions, and to make them wisely and make them well." However, she explained that making wise decisions about raw milk consumption can be difficult because federal discourses "often discourage raw milk drinking as a way of promoting public health, [which] ignores the fact that raw milk has some public benefits." She believed that federal agencies "are unwilling to give a more subtle message to the public," while "the public is capable of understanding a subtle milk-a subtle message."

Vermont's laws permitting the sale and consumption of raw milk honored the public's ability to make sense of "subtle messages" about risk, yet may be confusing to consumers since the federal discourses are so frightening. The discrepancy between federal recommendations and Vermont laws muddied the definition of "official" health and risk recommendations and institutionalized directly conflicting advice.

\section{Medical advice}

Official discourses are not exclusively within the legal or political system; however, interviewees noted that health practitioners often echo the federal risk discourses regarding raw milk. Some interviewees noted that they had had difficulties finding doctors who were permissive of their raw milk habits, particularly during pregnancy. Holly, who felt that drinking raw milk kept her healthy, wanted to continue drinking it throughout her pregnancy and took this into consideration while searching for a doctor. "We sort of gravitated towards healthcare providers that said, 'We have to tell you that you shouldn't, but we also support you doing what you feel is right."' Olivia, on the other hand, chose not to tell her doctor that she consumed raw milk while pregnant: "I go to a fairly progressive doctor. I don't think they would have an issue with it, or maybe they would ... but I didn't talk to them about it." Both Holly and Olivia chose to consume 
raw milk because they believed it was the healthiest option for them, rather than accepting what the probabilistic risk discourse of the medical establishment said would keep them healthiest.

\section{Advocacy literature}

Beyond regulatory and medical advice on raw milk, interviewees gathered much of their information from a variety of sources, including books and other publications, videos, educational lectures, and the internet. The most prominent sources that interviewees discussed were advocate voices such as Rural Vermont and the Weston A. Price Foundation, which both offer information regarding raw milk on their websites. The Weston A. Price Foundation, founded in 1999, is dedicated to spreading the nutritional theories of Dr. Weston A. Price, an Ohio dentist who practiced in the late 1800s and early 1900s and theorized that nutrient-rich diets like those consumed in pre-industrial societies are the healthiest diets (Weston A. Price Foundation, 2011). As an international organization, the Foundation has a great deal of information available to the general public, including founder Sally Fallon Morell's cookbook Nourishing Traditions, several documentaries and books, the website https://realmilk.com, and public lectures, such as Morell's talk in Burlington in June 2012. Interviewees referred to the Weston A. Price Foundation, which advocates nationally for raw milk access and consumption, as a "really good source of information" (Hannah), and described it as "the biggest proponent of raw milk" (Maggie). In nearly all interviews, the foundation and its work came up either directly or indirectly. Many perceived its website and publications to be the most complete resource on raw milk available on the internet, citing information from the foundation as a rebuttal to federal risk discourses.

\section{Circumventing the contest of voices}

Interviewees expressed frustration with the divergent raw milk discourses they found. They cited a variety of alternative voices, but many also acknowledged that conflicting, shifting voices were overwhelming and made it difficult to decide one way or the other about raw milk consumption. Consumers turned instead to personal filters, in- cluding personal experience and community networks, to vet their decision to drink raw milk.

\section{Trust yourself}

While Jon had explored a variety of mediated discourses on raw milk, he felt the claims made by federal and state agencies did not line up with his own experiences:

I've gone on the FDA website, and even though I've been drinking raw milk for five or more years, it still kind of scares the shit out of you when they say, "You should never drink this under any conditions. It's a poison." But that's just not my experience. I've never gotten ill from drinking raw milk, and I don't know anybody that has.

To Jon and other interviewees, the severe risk discourses promoted by the federal government simply did not resemble what he saw of raw milk consumption. While he acknowledged that certain sicknesses were connected to raw milk consumption, nevertheless these anecdotes did not cause him to change his behavior.

Kate was aware of the potential risks of drinking raw milk, yet she was a regular drinker. She described a friend who held many of the same values that she did, but refused to drink raw milk:

We're very similar in terms of our food and health decisions, making food decisions more from an ecological perspective...with the exception of raw milk because her grandfather's brother died, it is believed, from raw milk. She says..." Having that in the back of my mind just does not allow me to pour a glass of milk for my child."

Kate noted that if, like her friend, she had known someone who had died or gotten seriously ill from raw milk, she might feel that it carried more risk. But her lack of any direct personal experience with raw milk's negative effects allowed her to choose to drink it and to feed raw milk to her daughter. Raw milk aligns with her ecological values, she enjoys the health benefits, and she has no personal experience to convince her that it is un- 
safe, so she chooses to drink raw milk. In so doing, she is making her decision based on a variety of factors she felt were important, contrary to the risk-based decision that dominant discourses would advocate.

\section{Trust your farmer}

Beyond personal experience, consumers also looked to the producer from whom they got their milk for guidance on purchasing and consuming raw milk. Since most farms in Vermont must sell it directly from the farm, part of the experience of raw milk consumption is interaction with the farmer. All the interviewees had relationships with the farmers, and many knew friends or acquaintances who purchased milk from the same farm. Pauline and her family have a strong personal connection to the raw milk they consume: her husband picks it up for her family along his milk truck-driving route and counts many of those farmers among his friends. She noted the value of his interactions with the farmers producing the milk: "A lot of our friends are farmers. My husband was a farmer for 20 years. ... So where else can you go to but directly to the source?" To Pauline, knowing a farmer and being closely acquainted with his or her practices was important as a way to determine from which farm to get her milk.

In visiting farms or receiving milk shares, interviewees regularly interacted with the farmers and valued those interactions over a supermarket-type experience. When Matt was looking for a place to buy raw milk, he chose a farm with overwhelmingly positive recommendations, both in person and online. The first time he purchased it, he went to the unoccupied farm store, took some milk and left too much money. Within minutes, he received a call asking him to come back to the farm and retrieve his change or take more milk. "I hadn't seen anybody, but there's no disconnect between the farmer and the consumer." He contrasted this experience with a supermarket transaction in which the service might have been less personal. Holly reported a similar feeling about the farm stand where she purchases milk by dropping money into a box and taking her milk. "They're trusting ... that people are going to do the right thing. I think that goes both ways. The farmer needs to trust the con- sumer, and the consumer needs to know and trust that the farmer's doing the right thing." Personal relationships and the trust that interviewees felt for their farmers figured prominently into their understandings of their consumption choices. Their interpretation of trustworthy raw milk hinged on personal bonds and experiences rather than on interpretation of risk.

Trust arose as a key variable even when the raw milk did not meet expected standards. Barbara noted that on a couple of occasions, her neighbor's milk "has almost seemed like it was soapy." On those occasions, she called her neighbor to report the taste, and her neighbor explained that milk from cows nearing the end of their lactation phase tastes different and contains different bacteria that give it an off flavor. "And so on both occasions, she's apologized profusely, giving me more milk, and actually finished drying off that cow." Yet Barbara said these two experiences never made her reconsider patronizing her neighbor's farm for milk. "I guess maybe it's because of the neighbor factor, the fact that we know her, that we trust her, and that we know she runs a very clean shop, that we're going to continue to buy milk from her." For Barbara, the farmer's accountability and honesty added to her personal loyalty and trust in the farmer, which in turn kept her on as a customer.

\section{Trust local farms}

Interviewees trusted not only farmers but the transparency of the production and distribution system the farmers ran. They could go to the farm and watch every step, from the cow to the bottle. This system allowed interviewees to keep an eye on the aspects of the farm business that they prioritized. "At least when I'm buying [raw] local, organic milk from people I know, I know exactly how they're raising the cows. I know exactly what their on-farm practices are. I know exactly how they use their profits," Bridget said. The topic of animal treatment came up in multiple interviews, and Eliza voiced support not only for the farmer she purchased her milk from but also for the cows: "I like having that relationship and knowing that the cows are being treated well." Jessie took an economic approach, emphasizing the impact of her dollars on the individuals within the system: "I'm 
paying them directly ... That's keeping our money here, and it's supporting someone that lives in [town], and they're going to hopefully spend that money elsewhere." To Jessie, purchasing raw milk directly allowed her to see not only where her food was coming from, but also where the money she paid for it was going. Many interviewees said they chose to drink raw milk in support of their local food system or economy.

This did not mean, however, that risk of illness did not play a role in consumer decision-making. Within the framework of local raw milk choices, risk avoidance emerged as one criterion for selecting which farm to support. Many noted that they had sought information on bacteria counts and dairy management practices before settling on a farm to patronize. Farms that sell raw milk to consumers in Vermont must post bacteria testing results publicly, and many said that their farmers offered more information on their operation and on raw milk in general at the farm stand. Pauline, whose husband drives a milk truck, said her family specifically chose farms to patronize based on the ones with the lowest bacteria counts. Juliana said, "The reason I trust [the farm where I buy raw milk] so much is because the owner has a degree in cellular biology. She's a scientist, and so I feel pretty confident that she understands how it all works and the importance of testing." Juliana had examined the information available, and she also felt that the farmer's background helped to maintain a clean and safe operation.

In fact, many interviewees said that due to the large number of steps between farm and supermarket shelves, pasteurized milk products actually presented the greater risk, and raw milk presented a means to mitigate that risk. Sibyl said, "I think that there's always risks in eating food that you haven't grown, so for me knowing as much of the food chain and value chain in between me and the farm is really important." To her, transparency was the best way to mitigate the constant risk of consumption. Interviewees most valued, and perceived the least risk in, the raw milk supply chain because they could see both where their food was coming from and where their money was going. Where federal governmental discourses advocate for pasteurization as a means to minimize risk, our interviewees conceptualized a value system in which knowing the source and the process through which the food arrived on their plate was the most important factor in minimizing the risks involved in eating.

\section{Discussion}

Our aim with this paper is primarily to bring attention to a group whose voice has been relatively quiet in the scholarly discussion surrounding raw milk: the consumers. We discovered that interviewees did not conceive of their decisions as being in direct opposition to or in support of particular raw milk discourses. Rather than relying on or making sense of the contest of raw milk voices, interviewees relied on the filters of personal experience and personal networks to create decision-making criteria regarding raw milk.

Both national and Vermont-based numbers suggest that a small but not insignificant minority chooses to drink raw milk, particularly in states that have created a legal way to obtain the substance. Yet the limited existing research on the topic tends to frame these consumers as aberrant. For example, Katafiasz and Bartlett (2012) noted that although consumers interviewed claimed that raw milk had health benefits, "there is little scientific evidence to support the beliefs regarding raw milk's health benefits" (p. 126). Much of the U.S. scholarly research focuses on animal science, health, and safety and quantitative consumption perspectives on raw milk. In contrast, very little research delves into consumer understandings of raw milk consumption, including why people choose to disregard recommendations that governmental sources frame as highly important. Our interviewees regularly consumed raw milk, most stating that they did not feel they were partaking in risky behavior. Rather, they drew on personal experiences and local networks to develop priorities that reflected their belief systems and concepts of community.

\section{Theoretical Implications}

Sociocultural risk theorists might theorize that raw milk consumers are seeking ways to offset a risk that they feel modernity and mechanization-in this case, pasteurization-have created. Beck (1992) would posit that the turn to unpasteurized 
milk is a reaction to new technologies that serve as "solutions to problems, but also as a cause of problems" (p. 156). Others, like Giddens (1991), would look to the conflicting authority voices arguing over risk, the voices that are speaking directly to raw milk consumers.

Some interviewees did express mistrust or frustration with pasteurization and its impact on their health, the taste of the milk, or the structure of the food system. As Giddens (1991) would suggest, many, too, were aware of the conflicting voices arguing for and against pasteurization of milk. However, unlike Beck or Gidden's theorizing, we found that the discussion was not based solely around a preoccupation with risk. While consumers were aware of conflicting risk discourses and governmental warnings, their decisions were not driven by those discourses. Most interviewees acknowledged that there was food risk associated with raw milk, but they also saw risks associated with other types of consumption. Their strongest convictions about raw milk came not from mediated sources or risk discourses, but from the personal, face-to-face experiences that they had with farmers and other citizens in their communities. Among the many priorities interviewees balanced to make consumption decisions, risk did not figure heavily.

It is important to note that our interviewees were not drinking raw milk due to a deficit of knowledge about its potential benefits or risks. Rather, they were knowledgeable of the positive and negative consequences. They used a different set of criteria to make their consumption decisions. As such, our interviewees could be considered conscious consumers (Brooker, 1976). DuPuis (2000) describes this intentional consumption as a form of politics, particularly with regards to the milk industry. Conscious consumers recognize the agency they have to make food decisions within given communication contexts. They are not always going to choose what is considered the "healthiest" food. These consumers can identify, analyze, and evaluate competing messages before making consumption decisions using their own criteria. Future scholarship should investigate methods for helping consumers develop the skills needed to be conscious consumers.

\section{Practical Implications}

The paper examines the controversial area of informed consumer decision-making, which results in a choice of a food considered hazardous by the FDA. Our findings suggest that rural Vermont communities influence raw milk consumption decisions because of the close connection to producers of raw milk. These findings have implications for risk communication and regulators.

\section{Local Food, Culture, and Risk V alues}

In many ways, the raw milk movement in Vermont has echoed a statewide rise in support for local food production. State agencies collaborated to write Vermont's Farm to Plate Strategic Plan, which sets goals for localizing agricultural production, in 2009, the same year that the legislature voted to allow on-farm raw milk sales (Vermont Sustainable Jobs Fund, 2009). Vermont's many farm-to-plate restaurants, and the highest number of farmers markets, farm stands, and community supported agriculture (CSA) farms per capita in the U.S., also highlight a push to localize agricultural production, distribution, and sales (Vermont Agency of Agriculture Food and Markets, 2014).

This study demonstrates how food and its consumption is a cultural practice that can supersede risk-society values. Organizations that promote raw milk consumption can draw on these cultural values of community and localization when marketing raw milk products. Also, our research demonstrates that conversations with producers have a strong appeal to raw milk drinkers. Effective marketing strategies for raw milk should be explored in more depth.

\section{Risk communication and regulators}

Although interviewees were not making their consumption decisions based on risk and safety, risk remains the primary form of communication for governmental authorities hoping to discourage raw milk consumption. State regulations in Vermont permit consumption of raw milk, yet public health and governmental warnings remain severe, such as the sign that must be placed where producers sell raw milk. This results in a portion of the population that willingly disregards governmental warnings and advice and thus receives no further 
guidance for vetting the safety of a raw milk source. In Vermont, some $11.6 \%$ of people have ignored those recommendations and received advice through alternative and personal communication channels (Leamy et al., 2014).

This is not to say that these public health warnings do not serve a purpose. Public health warnings are intended to keep the maximum number of people as safe as possible and limit government and producer liability if consumers do get sick. However, in this case, more than one-tenth of Vermont's population did not heed the advice of state and federal health recommendations (Leamy et al., 2014) and are left on their own to determine what is "safe" consumption of raw milk.

\section{Improving risk communication}

Our findings are valuable for public health and governmental agencies because they demonstrate the filters that raw milk consumers are using to make decisions regarding raw milk. Public health agencies can use our findings to craft future messages and methods of dissemination. For example, our findings suggest that raw milk consumers use relationships and conversations with farmers as key determinants in their decision to drink raw milk. It may be effective to educate farmers about ways to talk to consumers about risks associated with raw milk. Effectively communicating risks with raw milk drinkers needs to be explored in more depth.

\section{Future Research and Limitations}

We complicate the notion that consumers are simply flouting risk recommendations, instead revealing that interviewees are making informed decisions based on information that is not specifically risk-related, primarily through personal experience and community networks. It would be valuable for future research to determine if raw milk drinkers in locations outside Vermont are making their decisions using similar criteria.

The scope of the current study was limited to current raw milk drinkers, eliminating the perspec- tive of those who consciously choose not to or to discontinue drinking raw milk. These consumers are also making consumption decisions within a contest of discourses. It would be valuable for future research to examine how consumers who have consciously elected not to or to discontinue consuming raw milk make this decision amid conflicting discourses surrounding raw milk consumption, health, and risk. Do these consumers engage with the contest of voices differently? Do these consumers rely on discourses and/or personal filters to make their decisions against consuming raw milk?

Additionally, Vermont raw milk consumers operate under the permits and restrictions of statespecific laws, and further research could examine how state regulations affect consumer relationships with farm, farmer, and product. For example, Leamy et al. (2014) found that the most common trait of raw milk consumers was living in a rural area; many of our interviewees also live in rural areas, but as Vermont urban areas are fairly small, most of those who lived in urban areas also routinely traveled to the farm where they purchased raw milk. Further research could investigate how consumer rationales for purchasing and consuming raw milk differ in states where fewer raw milk consumers have relationships with the farmers; for example, in California inspected raw milk is available for sale in stores (California Department of Public Health, 2014).

\section{Concluding Thoughts}

We should not assume that all eaters opt into the culture of risk-society anxieties. Consumers can make very informed, conscious decisions that are considered risky by dominant health and governmental organizations. Raw milk consumption behaviors are not uninformed decisions. Based on our research, we believe consumers value raw milk because they place a premium on the symbolic and practical impacts of their consumer decisions within the Vermont food system.

\section{References}

American Farm Bureau. (2013). Raw milk policy development 2013 [Press release]. Washington, D.C.: American Farm Bureau. Retrieved from http://www.hoards.com/sites/default/files/IB/AFB-raw-milk.pdf

Beck, U. (1992). Risk society: Towards a new modernity. London: Sage. 
Berg, B. L. (2004). Qualitative research methods for the social sciences (5th ed.). Boston, MA: Pearson.

Born, B., \& Purcell, M. (2006). Avoiding the local trap: Scale and food systems in planning research. Journal of Planning Education and Research, 26(2), 195-207. https://doi.org/10.1177/0739456X06291389

Brooker, G. (1976). The self-actualizing socially conscious consumer. Journal of Consumer Research, 3(2), 107-112. https://doi.org/10.1086/208658

Burakoff, A., Brown, K., Knutsen, J., Hopewell, C., Rowe, S., Bennett, C., \& Cronquist, A. (2018). Outbreak of fluoroquinolone-resistant Campylobacter jejuni infections associated with raw milk consumption from a herdshare dairy-Colorado, 2016. Morbidity and Mortality Weekly Report, 67(5), 146-148. https://doi.org/10.15585/mmwr.mm6705a2

California Department of Public Health. (2014). Raw milk and raw milk dairy products. Sacramento: CDPH. Retrieved from https://www.cdph.ca.gov/Programs/CID/DCDC/Pages/RawMilkandRawDairyProducts.aspx

Donnelly, C., \& Pritchard, T. J. (2010). Do raw milk sales help or harm local dairy economies: The case of Vermont H.125 [Opportunities for Agriculture Working Paper Series v. 1., No. 5]. Burlington, VT: Center for Rural Studies, Food Systems Research Collaborative. Retrieved from https://ideas.repec.org/s/ags/uvtfwp.html

DuPuis, E. M. (2000). Not in my body: BGH and the rise of organic milk. Agriculture and Human Values, 17(3), $285-295$. https://doi.org/10.1023/A:1007604704026

DuPuis, E. M. (2002). Nature's perfect food: How milk became America's drink. New York: New York University Press.

Enticott, G. (2003). Risking the rural: Nature, morality and the consumption of unpasteurised milk. Journal of Rural Studies, 19(4), 411-424. http://doi.org/10.1016/S0743-0167(03)00023-8

Fuentes, M., \& Fuentes, C. (2015). Risk stories in the media: Food consumption, risk and anxiety. Food, Culture \& Society, 18(1), 71-87. https://doi.org/10.2752/175174415X14101814953882

Giddens, A. (1991). Modernity and self-identity: Self and society in the late modern age. Stanford, CA: Stanford University Press.

Glaser, B. G., \& Strauss, A. L. (1967). The discovery of grounded theory: Strategies for qualitative research. Chicago: Aldine. https://doi.org/10.1097/00006199-196807000-00014

Guest, G., MacQueen, K., \& Namey, E. (2012). Applied thematic analysis. Thousand Oaks, CA: Sage. https://dx.doi.org/10.4135/9781483384436

Hallberg, L. R. (2006). The "core category" of grounded theory: Making constant comparisons. International Journal of Qualitative Studies on Health and Well-Being, 1(3), 141-148. https:/ / doi.org/10.1080/17482620600858399

Hannon, K. (2009, March 20). Raw milk is gaining fans, but the science says it's dangerous. U.S. News and World Report. Retrieved from https://health.usnews.com/health-news/family-health/articles/2009/03/20/raw-milk-is-gainingfans-but-the-science-says-its-dangerous

Headrick, M. L., Timbo, B., Klontz, K. C., \& Werner, S. B. (1997). Profile of raw milk consumers in California. Public Health Reports, 112(5), 418-422. Retrieved from https://www.ncbi.nlm.nih.gov/pmc/articles/PMC1381950/

Katafiasz, A. R., \& Bartlett, P. (2012). Motivation for unpasteurized milk consumption in Michigan, 2011. Food Protection Trends, 32(3), 124-128. Retrieved from http://www.foodprotection.org/files/food-protection-trends/Mar-12-Bartlett.pdf

Leamy, R. J., Heiss, S. N., \& Roche, E. (2014). The impact of consumer motivations and sources of information on unpasteurized milk consumption in Vermont. Food Protection Trends, 34(4), 216-225. Retrieved from https://www.foodprotection.org/files/food-protection-trends/Jul-Aug-14-Leamy.pdf

National Association of State Departments of Agriculture (NASDA). (2011). NASDA releases raw milk survey [Press release]. Washington, D.C.: NASDA. Retrieved from https://www.nasda.org/news/new-raw-milk-survey-results-are-now-available

National Farmers Union. (2013). Policy of the NFU. (111 th Anniversary Convention, Springfield, MA). Retrieved from https://nfu.org/images/stories/policy/FINAL\%202013\%20policy.pdf

Östberg, J. (2003). What's eating the eater? Perspectives on the everyday anxiety of food consumption in late modernity. Lund, Sweden: Lund University, Lund Business Press. Retrieved from https://portal.research.lu.se/portal/files/5770558/1693261.pdf

Paxson, H. (2013). The life of cheese: Crafting food and value in America. Berkeley: University of California Press. https://doi.org/10.1525/california/9780520270176.001.0001 
Polkinghorne, D. E. (2005). Language and meaning: Data collection in qualitative research. Journal of Counseling Psychology, 52(2), 137-145. https://psycnet.apa.org/record/2005-03263-003

Pollan, M. (2013, May 15). Some of my best friends are germs. The New York Times Magazine. Retrieved from https://www.nytimes.com/2013/05/19/magazine/say-hello-to-the-100-trillion-bacteria-that-make-up-yourmicrobiome.html

Rahn, W. M., Gollust, S. E., \& Tang, X. Framing food policy: The case of raw milk. Policy Studies Journal, 45(2), 359-383. https://doi.org/10.1111/psj.12161

Researchware, Inc. (2011). Qualitative analysis with HyperRESEARCH. Randolph, MA: Researchware, Inc. https://www.researchware.com

Rhodes, M. T., Kuchler, F., McClelland, K., \& Hamrick, K. S. (2019). Consumer food safety practices: Raw milk consumption and food thermometer use (EIB No. 205). Washington, D.C.: U.S. Department of Agriculture Economic Research Service.

Retrieved from https://www.ers.usda.gov/webdocs/publications/91110/eib-205.pdf?v=675.4

Rural Vermont. (2019). Raw milk 101: What consumers need to know. Montpelier: Rural Vermont. Retrieved from https://rural-vermont-v1.squarespace.com/s/7-9-19-raw-milk-consumer-final-factsheet.pdf

Sale of Unpasteurized Milk Act. (2009). Montpelier: VT Gen. Assembly 247506.1 No. 62 (H.12). Retrieved from http://www.leg.state.vt.us/docs/2010/Acts/ACT062.pdf

Sawyer, S., Calderwood, L., Bothfeld, D., \& Perkins, K. (2010). Farm to Plate strategic plan. Appendix B: Revitalizing Vermont's dairy industry. Montpelier: Vermont Sustainable Jobs Fund, Vermont Farm to Plate Network. Retrieved from http://www.vtfarmtoplate.com/assets/plan sections/files/Appendix $\% 20 \mathrm{~B}$ Revitalizing $\% 20 \mathrm{Vermonts} \% 20 \mathrm{Dairy} \% 2$ 0Industry MAY\%202013.pdf

U.S. Food and Drug Administration. (2011). Raw milk questions \& answers. Retrieved from https://www.fda.gov/food/buy-store-serve-safe-food/raw-milk-questions-answers

Valchuis, L., Conner, D. S., Berlin, L., \& Wang, Q. (2015). Stacking beliefs and participation in alternative food systems. Journal of Hunger \& Environmental Nutrition, 10(2), 214-229. https://doi.org/10.1080/19320248.2015.1004211

Vermont Agency of Agriculture, Food and Markets (VAAFM). (2020). Vermont agriculture and food system plan: 2020. Montpelier: VAAFM. Retrieved from https://agriculture.vermont.gov/document/vermont-agriculture-and-food-system-plan-2020

Vermont Sustainable Jobs Fund (VSJF). (2009). Farm to Plate strategic plan, Chapter 1: Overview. Montpelier: VSJF. Retrieved from https://www.vtfarmtoplate.com/plan/chapter/chapter-1-overview

Weisbecker, A. (2007). A legal history of raw milk in the United States. Journal of Environmental Health, 69(8), 6263. Retrieved from https://marlerclark.com/pdfs/raw-milk-jeh.pdf

Weston A. Price Foundation. (2011). Healthy 4 life. Washington, D.C.: Weston A. Price Foundation. Retrieved from http://www.westonaprice.org/wp-content/uploads/healthy4life2011.pdf

Willis, C., Jørgensen, F., Aird, H., Elviss, N., Fox, A., Jenkins, C. ..., \& McLauchlin, J. (2018). An assessment of the microbiological quality and safety of raw drinking milk on retail sale in England. Journal of Applied Microbiology, 124(2), 535-546. https://doi.org/10.1111/jam.13660 